\title{
Materials Research- Revista Ibero-americana de Materiais Rigorosa, mas justa e educativa!
}

A partir deste número, a Materials Research (ex-Revista Brasileira de Materiais) internacionaliza-se e passa a denominar-se Revista Ibero-americana de Materiais. Boas-vindas aos novos editores associados: Alberto Caneiro da Argentina, Miguel Jose Yacaman do México e Jose Serafim Moya da Espanha, três pesquisadores de reputação internacional, que certamente enriquecerão o nosso corpo editorial.

Estamos também contatando pesquisadores do Chile, Venezuela e Portugal para ingressarem no nosso quadro de editores. Aproveitamos o ensejo para agradecer os editores associados cujos mandatos findaram: José Carlos D'Abreu, Luiz H. Leme Louro, Paulo Roberto Cetlin, Gustau Ferran e Elias Hage Jr.

Contamos agora com mais uma associada; a Sociedade Brasileira de Microscopia e Microanálise, cujo presidente é o prof. Walter José Botta Filho, um dos nossos editores associados. Salientamos também que outro de nossos editores, o prof. Antonio C. Hernandes, assumiu a presidência da Sociedade Brasileira de Crescimento de Cristais, nossa associada. Dessa forma, somadas às demais associações fundadores e parceiras da $M R$, estamos consolidando um poderoso corpo, de enorme potencial, que poderá contribuir efetivamente para a divulgação, financiamento e consolidação nacional e internacional da $M R$.

Este número antecede o XIV CBECIMAT, que será realizado em Águas de São Pedro. Foram submetidos aproximadamente 1.100 abstracts àquele congresso, recorde absoluto, que mostra o pulso da Ciência e Engenharia de Materiais no Brasil. Desses, 84 foram submetidos à $M R$ e já estão sendo julgados, cada um por 2 assessores ad-hoc. Portanto, essa rica carteira de trabalhos, somada a aproximadamente 25 trabalhos anteriormente submetidos e àqueles que chegam continuamente, deverá abastecer e garantir a qualidade e regularidade da revista no próximo ano.

Excluindo os três números especiais da $M R$, a média geral dos tempos de publicação para artigos submetidos diretamente ao editor principal, que contabiliza as diligências sugeridas pelos assessores e editor, continua sendo de 7 meses. Dos artigos submetidos à publicação a $M R$, aproximadamente $50 \%$ têm sido aceitos.

Os recursos para a editoração, produção gráfica e impressão deste nono número da $M R$ foram provenientes da FAPESP (autores vinculados a instituições paulistas) e do CNPq (artigos dos demais autores e versão eletrônica da revista). Esperamos no próximo ano contar com eventual saldo do XIV CBECIMAT, conforme decidido pela assembléia de criação da revista no XII CBECIMAT em 1996. Tal repasse dará, ao menos temporariamente, a tão almejada tranqüilidade financeira à revista. Agradecemos também o apoio do Departamento de Engenharia de Materiais - DEMa - da UFSCar pelo auxílio com as despesas de correio, fax e telefone; do NIT pela criação e manutenção da home-page e às secretarias da $\mathrm{ABC}, \mathrm{ABPol}$ e $\mathrm{ABM}$, que têm nos auxiliado na divulgação e no gerenciamento das assinaturas e dos recursos financeiros. Agradecemos também o apoio do Programa de Pós-Graduação em Engenharia e Ciência dos Materiais - PPGCEM - da UFSCar para a publicação do número anterior da revista.

Caro leitor, o convidamos a assinar e publicar na $M R$ ! O objetivo da revista é demonstrar a qualidade da produção científica nacional e ibero-americana na área de materiais e divulga-la internacionalmente. Nossa política editorial é pautada por análise rigorosa, mas justa e educativa!

Cordialmente

Edgar Dutra Zanotto

Editor Principal 30-10-2000 